\title{
A quantitative real-time PCR assay for Ehrlichia ruminantium using $\mathrm{pCS20}$
}

\author{
H.C. Steyn ${ }^{\mathrm{a},}$, A. Pretorius ${ }^{\mathrm{a}}$, C.M.E. McCrindle ${ }^{\mathrm{b}}$, C.M.L. Steinmann ${ }^{\mathrm{c}}$ and M. Van \\ Kleef $^{\text {a }}$
}

a Onderstepoort Veterinary Institute, Private Bag X5, Onderstepoort 0110, South Africa

b Section Veterinary Public Health, Department Paraclinical Sciences, Veterinary Faculty, University of Pretoria, Private Bag X04, Onderstepoort 0110, South Africa

c Department of Biomedical Sciences, Tshwane University of Technology, Pretoria, South Africa

\begin{abstract}
Heartwater is a tick borne disease that affects ruminants and wild animals in Africa south of the Sahara. It is caused by Ehrlichia ruminantium and transmitted by the tick Amblyomma hebraeum. The protocols currently used to detect heartwater take several days to complete. Here, we describe the development of a pCS20 quantitative real-time PCR TaqMan probe assay to detect E. ruminantium in livestock blood and ticks from the field. The assay is based on the conserved pCS20 gene region of E. ruminantium that contains two overlapping genes, $r n c$ and $c t a G$ [Collins, N.E., Liebenberg, J., De Villiers, E.P., Brayton, K.A., Louw, E., Pretorius, A., Faber, F.E., Van Heerden, H., Josemans, A., Van Kleef, M., Steyn, H.C., Van Strijp, M.F., Zweygarth, E., Jongejan, F., Maillard, J.C., Berthier, D., Botha, M., Joubert, F., Corton, C.H., Thomson, N.R., Allsopp, M.T., Allsopp, B.A., 2005. The genome of the heartwater agent Ehrlichia ruminantium contains multiple tandem repeats of actively variable copy number. PNAS 102, 838-843]. The pCS20 quantitative real-time PCR TaqMan probe was compared to the currently used pCS20 PCR and PCR ${ }^{32}$ P-probe test with regards to sensitivity, specificity and the ability to detect DNA in field samples and in blood from experimentally infected sheep. This investigation showed that the pCS20 quantitative real-time PCR TaqMan probe was the most sensitive assay detecting seven copies of DNA/ $\mu$ l of cell culture. All three assays, however, cross react with Ehrlichia canis and Ehrlichia chaffeensis. The pCS20 real-time PCR detected significantly more positive field samples. Both the PCR and pCS20 realtime PCR could only detect E. ruminantium parasites in the blood of experimentally infected sheep during the febrile reaction. The $\mathrm{PCR} /{ }^{32} \mathrm{P}$-probe assay, however, detected the parasite DNA 1 day before and during the febrile reaction. Thus, because this new quantitative pCS20 real-time PCR TaqMan probe assay was the most sensitive and can be performed within $2 \mathrm{~h}$ it is an effective assay for epidemiological surveillance and monitoring of infected animals.
\end{abstract}




\section{Article Outline}

1. Introduction

2. Materials and methods

2.1. Samples

2.2. DNA extraction

2.3. pCS20 PCR and the modified pCS20 PCR $/{ }^{32} \mathrm{P}$-probe

2.4. pCS20 quantitative real-time PCR TaqMan probe

2.5. Generation of the pCS20 plasmid standard curve in order to calculate plasmid copy numbers

2.6. Animals experimentally infected with E. ruminantium Welgevonden

2.7. Statistical analysis

3. Results

3.1. Sensitivity of the pCS20 real-time PCR assay

3.2. Specificity of the pCS20 real-time PCR assay

3.3. Detection of $\mathrm{pCS} 20$ in field samples

3.4. Detection of the parasite in experimentally infected sheep

4. Discussion

Acknowledgements

References

\section{Introduction}

Heartwater (also known as cowdriosis) is caused by the rickettsia Ehrlichia ruminantium and is transmitted to livestock and wild ruminants by Amblyomma hebraeum ticks in South Africa (Allsopp et al., 2005). The definitive method for diagnosis of heartwater is still the detection of clinical signs and a post mortem brain smear. DNA-based tests including a pCS20 based PCR and PCR $/{ }^{32}$ P-probe ([Waghela et al., 1991], [Steyn et al., 2003] and [Van Heerden et al., 2004b]) have been used to detect E. ruminantium both in ticks and ruminants. The PCR/probe-based assays are labour-intensive, time consuming (5 days) and requires handling of radioactive materials ([Contini et al., 2005] and [Monis et al., 2002]) while real-time PCR assays can detect parasite DNA within $70 \mathrm{~min}$, are more sensitive and less labour-intensive (Espy et al., 2006). E. ruminantium, quantitative real-time PCR was first used to detect the map1 gene in order to monitor cell culture vaccine production (Peixoto et al., 2005). Similarly, Postigo et al. (2007) quantified E. ruminantium DNA in ticks and in infected endothelial cell cultures using the map1-1 gene. However, both the map1 and map1-1 genes are known to be polymorphic (Allsopp et al., 2001) and therefore may not always be effective for detecting heartwater isolates in the field. In contrast, the pCS20 region is conserved and therefore ideal for diagnostics and epidemiological studies.

To exploit the advantages of real-time PCR a TaqMan probe was designed to recognise the most conserved pCS20 region in 15 different known E. ruminantium stocks. The sensitivity of the resulting test was compared to that of a standard pCS20 PCR (Steyn et 
al., 2003) and a modified pCS20 PCR/32 P-probe technique (Van Heerden et al., 2004b). Furthermore, the real-time PCR assay was used to test sheep that had been experimentally infected with the E. ruminantium Welgevonden strain to determine when after initial infection the test could indicate the presence and number of the organisms in the blood.

\section{Materials and methods}

\subsection{Samples}

Genomic DNA samples used in this study were isolated from infected cell cultures, experimentally infected animal blood and A. hebraeum tick and blood samples collected from the field.

E. ruminantium stocks used in this study were: Welgevonden, Mara87/7, Vosloo, Blaauwkrans, Kwanyanga, Ball3, Kümm1, Kümm2, and Nonile from South Africa. Senegal, Pokoase, Sankat, Mali from West Africa, Gardel isolated from Guadeloupe and Um Banein from the Sudan. All were cultured in vitro as described previously (Van Heerden et al., 2004b) and used as positive reference samples. Samples used as specificity controls were Ehrlichia canis, Ehrlichia chaffensis (known to cause crossreactions), Anaplasma centrale, Anaplasma marginale and Theileria parva. Whole blood (120) was collected from heartwater endemic areas of South Africa in sterile Vacutainer ${ }^{\circledR}$ tubes containing EDTA as anticoagulant and stored at $-20{ }^{\circ} \mathrm{C}$ until used.

Adult male and female A. hebraeum ticks (179) (on average five ticks per animal) feeding on cattle were collected from heartwater endemic areas in South Africa. The ticks were washed in $70 \%$ ethanol and were individually homogenised in $1.5 \mathrm{ml}$ sucrose potassium glutamate (Du Plessis, 1985). For DNA extraction, a $200 \mu$ l volume of the homogenised tick sample was used. The remainder was stored in liquid nitrogen.

\subsection{DNA extraction}

DNA was extracted from homogenised ticks using the cell culture genomic DNA isolation protocol from QIAamp ${ }^{\circledR}$ DNA blood mini kit (Qiagen) and from whole blood and cell culture material using the Generation ${ }^{\circledR}$ capture column kit (Qiagen) according to the manufacturer's instructions.

\section{3. pCS20 PCR and the modified pCS20 PCR/ ${ }^{32} \mathrm{P}$-probe}

The pCS20 PCR was performed as described by Steyn et al. (2003) using the primers HH1F and HH2R (Table 1) and TaKaRa Ex Taq ${ }^{\mathrm{TM}}$ (Takara Bio Inc.) (in a $50 \mu 1$ reaction mixture) to amplify a 903 bp product. Positive ( $1 \mu \mathrm{l}$ of Welgevonden plasmid DNA) and negative controls ( $5 \mu$ water) were included. Ten microlitres of each PCR product was separated on a $1 \%$ agarose gel, stained with ethidium bromide and visualised by UV transillumination. Aliquots $(10 \mu \mathrm{l})$ from each of the PCRs were also transferred to a nylon membrane using the Micro-sample Filtration Manifold (Minifold II, Schleicher and 
Schuell, Germany). The DNA was transferred under vacuum, fixed and probed as described previously (Van Heerden et al., 2004b).

Table 1.

Primer and probe sequences used in the three pCS20 assays

\begin{tabular}{|l|l|l|}
\hline Primers/probe & Sequences & $\begin{array}{l}\text { Annealing } \\
\text { temperature } \\
\left({ }^{\circ} \mathbf{C}\right)\end{array}$ \\
\hline HH1F & $\begin{array}{l}5^{\prime} \text {-CCC TAT GAT ACA GAA GGT AAC CTC GC- } \\
3^{\prime}\end{array}$ & 62 \\
\hline HH2R & $5^{\prime}$-GAT AAG GAG ATA ACG TTT GTT TGG-3' & 62 \\
\hline AB128 (probe) & $5^{\prime}$-ACT AGT AGA AAT TGC ACA ATC TAT-3' & 55 \\
\hline AB129 (probe) & $5^{\prime}$-TGA TAA CTT GGT GCG GGA AAT CCT T-3' & 55 \\
\hline CowF & $5^{\prime}$-CAA AAC TAG TAG AAA TTG CAC A-3' & 48 \\
\hline CowR & $5^{\prime}$-TGC ATC TTG TGG TGG TAC-3' & 48 \\
\hline Cow ${ }^{\mathrm{TM}}$ (probe) & $\begin{array}{l}5^{\prime} \text { 6FAM TCC TCC ATC AAG ATA TAT AGC } \\
\text { ACC TAT TA XT-PH-3' }\end{array}$ & 58 \\
\hline
\end{tabular}

\section{4. pCS20 quantitative real-time PCR TaqMan probe}

Real-time PCR was performed in a LightCycler ${ }^{\circledR}$ system using the LightCycler FastStart DNA Master Hybridization Probe kit from Roche Diagnostics. The CowF forward and CowR reverse primers (Table 1) were designed to amplify a $226 \mathrm{bp}$ fragment of the conserved pCS20 region. A TaqMan probe $\mathrm{Cow}^{\mathrm{TM}}$ (Table 1) was designed $120 \mathrm{bp}$ from the forward primer and synthesised by TIB-Molbiol, Berlin, Germany. Each reaction mixture contained $2 \mu \mathrm{l}$ of DNA as template and a final concentration of $4 \mathrm{mM} \mathrm{MgCl}_{2}$, $0.5 \mu \mathrm{M}$ of each primer, $0.4 \mu \mathrm{M}$ probe, 1 U Uracil DNA $N$-Glycosylase (UNG) and $5 \mathrm{U}$ taq polymerase (Roche). All reactions included a pure water negative control and pCS20 plasmid DNA ( $10^{-1}$ dilution) as a positive control. UNG was added to reduce possible contamination. Thermal cycling with an initial incubation of $10 \mathrm{~min}$ at $40^{\circ} \mathrm{C}$ was followed by a denaturing for $10 \mathrm{~min}$ at $95^{\circ} \mathrm{C}$. This was then followed by 38 cycles of denaturing at $95{ }^{\circ} \mathrm{C}, 10 \mathrm{~s}$ with a $20^{\circ} \mathrm{C} / \mathrm{s}$ slope, annealing at $48{ }^{\circ} \mathrm{C}, 10 \mathrm{~s}$ with a $20^{\circ} \mathrm{C} / \mathrm{s}$ slope and elongation at $58{ }^{\circ} \mathrm{C}, 30 \mathrm{~s}$ with a $20^{\circ} \mathrm{C} / \mathrm{s}$ slope, and a final cooling step to $40{ }^{\circ} \mathrm{C}$. Fluorescence data was acquired at the end of the extension step of each cycle. Data was analysed using LightCycler ${ }^{\circledR}$ software-4.0 (Roche). A threshold cycle of 38 was selected as the detection limit of this assay. 


\subsection{Generation of the pCS20 plasmid standard curve in order to calculate plasmid copy numbers}

The copy number of the pCS20 region was calculated by generating a standard curve using a pGEM ${ }^{\circledR}$-T_pCS20 construct containing the 903 bp pCS20 region amplified using primers HH1F and HH2R (Table 1). Three replicates of 10-fold serial dilutions of plasmid DNA $\left(10^{-1}\right.$ to $\left.10^{-8}\right)$ were prepared (starting concentration $10 \mu \mathrm{g} / \mu \mathrm{l}$ ) in elution buffer and used to generate a standard curve. Knowing the size of the plasmid that contains the pCS20 region, the copy numbers of the plasmid could be calculated ([Doyle et al., 2005] and [Peixoto et al., 2005]). The standard curve was used to measure DNA concentration which was converted to number of $\mathrm{pCS} 20$ copies $/ \mathrm{ml}$ blood using the calculations described by Doyle et al. (2005).

\subsection{Animals experimentally infected with $E$. ruminantium Welgevonden}

Six to eight-month-old merino sheep obtained from a heartwater-free region in South Africa were experimentally infected with E. ruminantium Welgevonden. Five sheep, that tested negative with all three pCS20 assays, were bled to collect uninfected blood before they were injected i.v. with $10 \mathrm{LD}_{50} \mathrm{~s}$ Welgevonden challenge material (Brayton et al., 2003). Blood $(10 \mathrm{ml})$ was collected daily into EDTA tubes from each sheep until the animals were treated on the third day of febrile reaction when their temperatures had reached $41.5-42{ }^{\circ} \mathrm{C}$. Rectal temperatures were measured daily starting 10 days before infection after which sheep were also monitored for the onset of heartwater clinical signs. Infection was monitored by extracting DNA from blood $(200 \mu \mathrm{l})$ collected from each of the sheep from day 0 to the third day of elevated temperatures. All animal work was approved by the Agricultural Research Council, Onderstepoort Veterinary Institute Ethics Committee. Genomic DNA was tested in triplicate with the pCS20 real-time PCR, modified pCS20 PCR $/{ }^{32} \mathrm{P}$-probe and standard PCR. The pCS20 concentration of each sample was determined using a pCS20 plasmid standard curve and the pCS20 copy number was calculated for each sample.

\subsection{Statistical analysis}

Blood and tick field samples were compared by means of the one-tailed Student's $t$-test. Significance was assessed at $P$-values of $\leq 0.01$.

\section{Results}

\subsection{Sensitivity of the pCS20 real-time PCR assay}

In order to compare the sensitivity of the assays, the number of pCS20 copies/ $\mu 1$ were determined by calculating the copy number of pCS20 using a pCS20 plasmid standard curve. Fluorescence was detected by real-time PCR at an average crossing point starting at 8.58 for the undiluted sample up to 31.15 for the highest dilution $\left(10^{-6}\right)$. The amplification efficiency of the standard curve was 1.981. Successful amplification was obtained up to a dilution of $1 \mathrm{fg} / \mu \mathrm{l}$ of plasmid which correlates with the amplification of one copy of the plasmid in a $20 \mu$ reaction. 
The analytical sensitivity of the pCS20 real-time PCR assay was compared to the standard pCS20 PCR and the modified pCS20 PCR ${ }^{32}$ P-probe using DNA of the Welgevonden stock that was purified from cell culture. Using the diluted purified genomic Welgevonden stock DNA as a template, the standard PCR could detect pCS20 at a dilution of $10^{-6}(700 \mathrm{pCS} 20$ copies $/ \mu \mathrm{l})$ with the $\mathrm{PCR} /{ }^{32} \mathrm{P}$-probe still able to show a hybridisation signal at $10^{-7}(70 \mathrm{pCS} 20$ copies $/ \mu \mathrm{l})$. The pCS20 real-time PCR could detect pCS20 DNA at a further 10 -fold higher dilution, i.e. $10^{-8}$ ( $7 \mathrm{pCS} 20$ copies/ $\left.\mu \mathrm{l}\right)($ Table 2$)$. These assays were repeated three times and the same results were obtained each time.

Table 2.

Comparison of the sensitivity of three pCS20 assays using serially diluted Welgevonden infected cell culture material DNA

\begin{tabular}{|c|c|c|c|c|}
\hline Dilution $^{a}$ & Copy number (copies/ $\mu \mathrm{l})$ & $\mathbf{P C R}^{\mathbf{a}}$ & PCR $/{ }^{32}$ P-probe ${ }^{a}$ & TaqMan $^{a}$ \\
\hline $10^{-1}$ & $7 \times 10^{7 b}$ & $+^{\mathrm{c}}$ & + & + \\
\hline $10^{-2}$ & $7 \times 10^{6}$ & + & + & + \\
\hline $10^{-3}$ & $7 \times 10^{5}$ & + & + & + \\
\hline $10^{-4}$ & $7 \times 10^{4}$ & + & + & + \\
\hline $10^{-5}$ & $7 \times 10^{3}$ & + & + & + \\
\hline $10^{-6}$ & $7 \times 10^{2}$ & + & + & + \\
\hline $10^{-7}$ & $7 \times 10^{1}$ & $-{ }^{d}$ & + & + \\
\hline $10^{-8}$ & $7 \times 10^{0}$ & - & - & + \\
\hline
\end{tabular}

${ }^{a}$ Performed in triplicate.

${ }^{\mathrm{b}}$ Dilutions of Welgevonden infected cell culture material.

${ }^{\mathrm{c}}$ Positive.

${ }^{\mathrm{d}}$ Negative.

\subsection{Specificity of the pCS20 real-time PCR assay}

The specificity of the pCS20 TaqMan probe was determined in triplicate using a total of 15 known E. ruminantium stocks, T. parva and four other Rickettsiales namely E. canis, Ehrlichia chaffeensis, A. centrale and A. marginale. The pCS20 real-time PCR assay specifically detected all E. ruminantium stocks while the PCR and PCR $/{ }^{32} \mathrm{P}$-probe detected all but one, the Kümm2 stock. The pCS20 PCR, modified pCS20 PCR ${ }^{\beta 2} \mathrm{P}$-probe and pCS20 real-time PCR were positive with E. canis and E. chaffeensis but negative with T. parva, A. centrale and A. marginale DNA (Table 3). The copy number of each of the reference samples was also calculated (Table 3 ) and all of the samples were determent to be above the PCR detection limits. All the PCR positive samples were sequenced to confirm that $E$. ruminantium pCS20 DNA was amplified. 
Table 3.

Specificity of the three pCS20 assays using genomic DNA of known E. ruminantium stocks and five closely related bacteria

\begin{tabular}{|c|c|c|c|c|}
\hline Samples & $\begin{array}{l}\text { PCR } \\
\text { positive }^{\text {a }}\end{array}$ & $\begin{array}{l}{ }^{32} \text { P-probe } \\
\text { positive }^{\mathrm{a}}\end{array}$ & $\begin{array}{l}\text { TaqMan } \\
\text { probe } \\
\text { positive }^{\text {a }}\end{array}$ & $\begin{array}{l}\text { Copy } \\
\text { number } \\
(\text { copies/ } \boldsymbol{\mu l})\end{array}$ \\
\hline Welgevonden & $+^{\mathrm{b}}$ & + & + & $7 \times 10^{8}$ \\
\hline Mara87/7 & + & + & + & $1 \times 10^{8}$ \\
\hline Vosloo & + & + & + & $3 \times 10^{6}$ \\
\hline Blaauwkrans & + & + & + & $1 \times 10^{9}$ \\
\hline Kwanyanga & + & + & + & $4 \times 10^{8}$ \\
\hline Ball3 & + & + & + & $4 \times 10^{6}$ \\
\hline Kümm1 & + & + & + & $5 \times 10^{4}$ \\
\hline Kümm2 & $-^{\mathrm{c}}$ & - & + & $1 \times 10^{7}$ \\
\hline Gardel & + & + & + & $1 \times 10^{9}$ \\
\hline Senegal & + & + & + & $7 \times 10^{7}$ \\
\hline Pokoase & + & + & + & $9 \times 10^{7}$ \\
\hline Sankat & + & + & + & $1 \times 10^{9}$ \\
\hline Mali & + & + & + & $1 \times 10^{8}$ \\
\hline Um Banein & + & + & + & $5 \times 10^{4}$ \\
\hline Nonile & + & + & + & $6 \times 10^{7}$ \\
\hline Ehrlichia canis & + & + & + & $1 \times 10^{4}$ \\
\hline Ehrlichia chaffeensis & + & + & + & $2 \times 10^{3}$ \\
\hline Theileria parva & - & - & - & $3 \times 10^{6 d}$ \\
\hline Anaplasma centrale & - & - & - & $4 \times 10^{6 d}$ \\
\hline Anaplasma marginale & - & - & - & $4 \times 10^{6 \mathrm{~d}}$ \\
\hline
\end{tabular}

${ }^{\text {a }}$ Performed in triplicate.

${ }^{\mathrm{b}}$ Positive.

${ }^{\mathrm{c}}$ Negative.

${ }^{\mathrm{d}}$ Calculated genome copy numbers. 


\subsection{Detection of pCS20 in field samples}

The ability of the real-time PCR assay to detect E. ruminantium in field samples was determined. Blood was collected from 120 cattle that showed no symptoms of heartwater or any other disease. Twenty samples tested positive with the real-time PCR, of these 17 tested positive with the modified pCS20 PCR $/ 22$-probe and 16 with the standard PCR. The remaining blood samples $(n=100)$ were negative with all three tests. The pCS20 real-time PCR detected significantly more positive blood samples than the standard PCR $(P \leq 0.001)$. Of the 179 tick samples tested, 79 samples tested positive with the pCS20 real-time PCR. Using the same genomic DNA from these positive real-time PCR samples, only 66 tested positive with the pCS20 PCR/ ${ }^{32} \mathrm{P}$-probe and 54 with the pCS20 PCR. The remaining 100 individual ticks tested negative with all three tests. Significantly more positive tick samples were detected by the real-time PCR than the $\mathrm{pCS} 20 \mathrm{PCR} /{ }^{32} \mathrm{P}$ probe $(P \leq 0.00001)$ or with the standard PCR $(P \leq 0.00000003)$. Therefore, the real-time PCR assay was more sensitive when tick stabilates were used as starting material. However, no significant difference was observed between the ${ }^{32} \mathrm{P}$-probe and real-time PCR if the genomic DNA target had been isolated from blood.

\subsection{Detection of the parasite in experimentally infected sheep}

The real-time PCR could detect the parasite in the blood of infected animals once their temperature had risen above $41.5^{\circ} \mathrm{C}$ (days $12-14$ ) and the $\mathrm{PCR} /{ }^{32} \mathrm{P}$-probe from $40{ }^{\circ} \mathrm{C}$ (days 11-14). Testing was terminated once the animals were treated with Terramycin ${ }^{\circledR} 100$ (Table 4). The number of parasites per millilitre of febrile stage blood was determined by using a pCS20 plasmid standard curve. A range of $4.3 \times 10^{8}-2 \times 10^{9}$ pCS2 0 copies per $1 \mathrm{ml}$ blood was found in the febrile stage of the five infected sheep (Table 5).

Table 4.

Comparison of the ability of the three pCS20 assays to detect E. ruminantium in sheep experimentally infected with the Welgevonden stock

\begin{tabular}{|l|l|l|l|}
\hline Day & PCR & PCR $^{32}$ P-probe & Real-time PCR \\
\hline 0 & - d & - & - \\
\hline 1 & - & - & - \\
\hline 2 & - & - & - \\
\hline 3 & - & - & - \\
\hline 4 & - & - & - \\
\hline 5 & - & - & - \\
\hline 6 & - & - & - \\
\hline 7 & - & - & - \\
\hline 8 & - & - & - \\
\hline 9 & - & - & - \\
\hline
\end{tabular}




\begin{tabular}{|l|l|l|l|}
\hline Day & PCR & PCR $/{ }^{32}$ P-probe & Real-time PCR \\
\hline 10 & - & - & - \\
\hline 11 & - & $5+/ 5^{\mathrm{e}}$ & - \\
\hline $12^{\mathrm{a}}$ & - & $5+/ 5$ & $5+/ 5$ \\
\hline $13^{\mathrm{a}}$ & $5+/ 5$ & $5+/ 5$ & $5+/ 5$ \\
\hline $14^{\mathrm{a}}$ & $5+/ 5$ & $5+/ 5$ & $5+/ 5$ \\
\hline $15^{\mathrm{b}}$ & $\mathrm{n} / \mathrm{d}^{\mathrm{c}}$ & $\mathrm{n} / \mathrm{d}$ & $\mathrm{n} / \mathrm{d}$ \\
\hline
\end{tabular}

${ }^{\mathrm{a}}$ Febrile reaction.

${ }^{\mathrm{b}}$ Treated.

${ }^{\mathrm{c}}$ Samples were not tested.

d Negative.

${ }^{\mathrm{e}}$ Number of sheep that tested positive.

Table 5.

E. ruminantium parasite concentration determined on the third day of febrile reaction of experimentally infected sheep

\begin{tabular}{|l|l|}
\hline Sheep number & Average parasite copies per ml blood \\
\hline 861 & $1 \times 10^{9}$ \\
\hline 862 & $2 \times 10^{9}$ \\
\hline 869 & $4 \times 10^{8}$ \\
\hline 870 & $7 \times 10^{8}$ \\
\hline 871 & $4 \times 10^{8}$ \\
\hline
\end{tabular}

\section{Discussion}

A quantitative real-time PCR TaqMan probe assay based on a sequence in the pCS20 region for the detection of the E. ruminantium genome was developed. Its analytical sensitivity (Table 2) and specificity (Table 3 ) were compared with two other tests, namely a standard PCR and a modified pCS20 PCR/32 P-probe ([Steyn et al., 2003] and [Van Heerden et al., 2004b]). The detection limit for the real-time PCR using infected cell culture was 100-fold higher than the standard PCR. More tick samples tested positive using the real-time PCR assay than the other two assays, probably as a result of its higher sensitivity. Of the 179 A. hebraeum ticks collected from endemic areas, 79 tested positive using the real-time PCR, while 66 were positive with the pCS20 PCR $/{ }^{32} \mathrm{P}$-probe. Only 54 tested positive with the standard PCR. Under optimum conditions, therefore the real-time PCR could detect lower concentrations of the pCS20 DNA. These results thus indicate 
that the real-time PCR assay is more suitable for epidemiological studies and diagnostic tests.

The standard pCS20 PCR as modified by Van Heerden et al. (2004b) amplifies a 903 bp product from all the characterised E. ruminantium stocks known, including the Kümm2 stock originally isolated by Zweygarth et al. (2002). In this present study, however, Kümm2 DNA could only be detected by the pCS20 real-time PCR even though the DNA concentration was above the detection limit for all three assays. Compared to the conserved pCS20 sequences of the 14 other E. ruminantium stocks, the Kümm2 pCS20 sequence differs by 39 out of the $279 \mathrm{bp}$ in the region used for the ${ }^{32} \mathrm{P}$-probe prepared using the $\mathrm{AB} 128 \mathrm{~F}$ and $\mathrm{AB} 129 \mathrm{R}$ primers. In contrast the TaqMan probe is smaller $(29 \mathrm{bp})$ and targets a region of the pCS20 DNA, where the Kümm2 and the 14 other stock sequences only vary by two nucleotides. The TaqMan probe is therefore in theory more likely to detect other E. ruminantium genotypes.

A close phylogenetic relationship exists between E. chaffeensis, E. canis and E. ruminantium ([Dumler et al., 2001] and [Van Heerden et al., 2004a]). This may explain why the PCR assays cross react. However, because E. chaffeensis does not occur in South Africa and E. canis causes a disease in dogs their DNA should therefore not pose a problem for real-time PCR detection of heartwater.

Real-time PCR, using the map1 multigene family, was shown to be a more accurate method for quantification of E. ruminantium than the counting of fluorescence stained parasites. Counting is made difficult by the presence of endothelial cell nuclei and aggregation of the parasites (Peixoto et al., 2005). In this study, pCS20 real-time PCR was used to quantify the number of parasites in experimentally infected sheep blood using a pCS20 plasmid standard curve. Because each plasmid contains one copy of pCS20 one can assume that each copy of plasmid correlates to one copy of pCS20. Furthermore, there is one copy of pCS20 per genome equivalent of E. ruminantium (Collins et al., 2005). Therefore, it can be assumed that each copy of pCS20, measured by the real-time PCR assay, is equivalent to one genome copy of E. ruminantium. The pCS20 TaqMan probe assay indicated that approximately $10^{8}-10^{9}$ E. ruminantium parasites per millilitre blood were present in all five sheep infected with Welgevonden blood stabilate. This correlated with the amount of parasites that were found in cell culture $\left(10^{9}\right.$ copies $\left./ \mathrm{ml}\right)$ using the map1 real-time PCR (Peixoto et al., 2005). Postigo et al. (2007) reported quantification of E. ruminantium in the midgut and salivary glands in ticks $\left(10^{6}\right.$ bacteria per tick) by real-time PCR using the map1 multigene family. The real-time PCR could only detect E. ruminantium parasites in the blood of infected animals at the febrile stage of infection. This could be linked to the life cycle of the parasite in the ruminant host. After an infected tick bite, the initial replication of the organism takes place in reticulo-endothelial cells within the lymph nodes (Allsopp et al., 2005). Furthermore, it has been postulated that the febrile stage coincides with the movement of organisms from the lymph to the bloodstream (Du Plessis, 1970). This is probably why organisms could not be detected in the circulating blood of experimental sheep infected with Welgevonden blood stabilate before the febrile stage. In contrast, field samples obtained from healthy cattle tested positive with the real-time PCR. These 
animals can therefore be considered to be in a putative carrier state. It has been known for many years that animals can have a "premunity" (in other words, heartwater organisms remain in the animal and stimulate ongoing immunity, with no symptoms being shown) that results in endemic stability of heartwater (Allsopp et al., 2005).

The pCS20 PCR $/{ }^{32} \mathrm{P}$-probe could detect the pCS20 DNA 11 days after infection while the real-time PCR could only detect the DNA from day 12 onwards. Even though the statistical significance of these findings could be further verified by using a larger group of experimental animals, this result is surprising because with cell culture samples the real-time PCR could detect a 10 -fold higher dilution than the $\mathrm{pCS} 20 \mathrm{PCR} /{ }^{32} \mathrm{P}$-probe. The fact that the probe could detect pCS20 DNA earlier, and therefore at lower concentrations, may be as a result of inhibitory compounds in the DNA isolated from whole blood. Various substances including haemoglobin, immunoglobulin G, urea, anticoagulants like EDTA and heparin, high concentrations of leukocyte DNA, plasma and other unknown inhibitors in blood samples have been shown to inhibit real-time PCR ([Wilson, 1997], [Al-Soud et al., 2000] and [Al-Soud and Rådström, 2001]). If so, different DNA extraction methods should be tested (Flekna et al., 2007).

In conclusion, the pCS20 real-time PCR was more sensitive than the standard PCR and modified pCS20 PCR $/{ }^{32} \mathrm{P}$-probe when applied to cell culture, blood and tick DNA. Infected animals could be diagnosed before they succumb and can thus be treated appropriately. Furthermore, DNA in the samples could be quantified, making it suitable for diagnostic and epidemiological studies.

\section{References}

Allsopp et al., 2005 B.A. Allsopp, J.D. Bezuidenhout and L. Prozesky, Heartwater (second ed.). In: J.A.W. Coetzer and R.C. Tustin, Editors, Infectious Diseases of Livestock vol. 2, ABC Press, Cape Town (2005), pp. 507-535.

Allsopp et al., 2001 M.T.E.P. Allsopp, C.M. Dorflin, G.J.C. Maillard, A. Bensaid, D.T. Haydon, H. Van Heerden and B.A. Allsopp, Ehrlichia ruminantium major antigenic protein gene (map1), J. Clin. Microbiol. 39 (2001), pp. 4200-4203.

Al-Soud et al., 2000 W.B. Al-Soud, L.J. Jönsson and P. Rådström, Identification and characterization of immunoglobulin $\mathrm{G}$ in blood as a major inhibitor of diagnostic PCR, $J$. Clin. Microbiol. 38 (2000), pp. 345-350.

Al-Soud and Rådström, 2001 W.B. Al-Soud and P. Rådström, Purification and characterization of PCR-inhibitory components in blood cells, J. Clin. Microbiol. 39 (2001), pp. 485-493.

Brayton et al., 2003 K.A. Brayton, N.E. Collins, F. Van Strijp and B.A. Allsopp, Preparation of Ehrlichia ruminantium challenge material for quantifiable reproducible challenge in mice and sheep, Vet. Parasitol. 112 (2003), pp. 63-73. 
Collins et al., 2005 N.E. Collins, J. Liebenberg, E.P. De Villiers, K.A. Brayton, E. Louw, A. Pretorius, F.E. Faber, H. Van Heerden, A. Josemans, M. Van Kleef, H.C. Steyn, M.F. Van Strijp, E. Zweygarth, F. Jongejan, J.C. Maillard, D. Berthier, M. Botha, F. Joubert, C.H. Corton, N.R. Thomson, M.T. Allsopp and B.A. Allsopp, The genome of the heartwater agent Ehrlichia ruminantium contains multiple tandem repeats of actively variable copy number, PNAS 102 (2005), pp. 838-843.

Contini et al., 2005 C. Contini, S. Seraceni, R. Cultrera, C. Incorvaia, A. Sebastiani and S. Picot, Evaluation of a real-time PCR-based assay using the lightcycler system for detection of Toxoplasma gondii bradyzoite genes in blood specimens from patients with toxoplasmic retinochoroiditis, Int. J. Parasitol. 35 (2005), pp. 275-283.

Doyle et al., 2005 C.K. Doyle, M.B. Labruna, E.B. Breitschwerdt, Y. Tang, R.E. Corstvet, B.C. Hegary, K.C. Bloch, P. Li, D.H. Walker and J.W. McBride, Detection of medically important Ehrlichia by quantitative multicolor TaqMan real-time polymerase chain reaction of the $d s b$ gene, J. Mol. Diag. 7 (2005), pp. 504-510.

Du Plessis, 1970 J.L. Du Plessis, Pathogenesis of heartwater. I. Cowdria ruminantium in the lymph nodes of domestic ruminants, Onderstepoort J. Vet. Res. 37 (1970), pp. 89-95.

Du Plessis, 1985 J.L. Du Plessis, A method for determining the Cowdria ruminantium infection rate of Amblyomma hebraeum: effects in mice injected with tick homogenates, Onderstepoort J. Vet. Res. 52 (1985), pp. 55-61.

Dumler et al., 2001 J.S. Dumler, A.F. Barbet, C.P. Bekker, G.A. Dasch, G.H. Palmer, S.C. Ray, Y. Rikihisa and F.R. Rurangirwa, Reorganisation of genera in the families Rickettsiaceae and Anaplasmataceae in the order Rickettsiales: unification of some species of Ehrlichia and Anaplasma, Cowdria with Ehrlichia and Ehrlichia with Neorickettsia, descriptions of six new species combinations and designation of Ehrlichia equi and HE agent as subjective synonyms of Ehrlichia phagocytophila, Int. J. Syst. Evol. Microbiol. 51 (2001), pp. 2145-2165.

Espy et al., 2006 M.J. Espy, J.R. Uhl, L.M. Sloan, S.P. Buckwalter, M.F. Jones, E.A. Vetter, J.D.C. Uao, N.L. Wengenack, J.E. Rosenblatt, F.R. Cockerill III and T.F. Smith, Real-time PCR in clinical microbiology: applications for routine laboratory testing, Clin. Microbiol. Rev. 19 (2006), pp. 165-256.

Flekna et al., 2007 G. Flekna, W. Schneeweiss, F.J.M. Smulders, M. Wagner and M.I. Hein, Real-time PCR method with statistical analysis to compare the potential of DNA isolation methods to remove PCR inhibitors from samples for diagnostic PCR, Mol. Cell. Probes 21 (2007), pp. 282-287.

Monis et al., 2002 P.T. Monis, R.H. Andrews and C.P. Saint, Invited review: molecular biology techniques in parasite ecology, Int. J. Parasitol. 32 (2002), pp. 551-562. 
Peixoto et al., 2005 C.C. Peixoto, I. Marcelino, N. Vachiéry, A. Bensaid, D. Martinez, M.J.T. Carrondo and P.M. Alves, Quantification of Ehrlichia ruminantium by real time PCR, Vet. Microbiol. 107 (2005), pp. 237-278.

Postigo et al., 2007 M. Postigo, A. Taoufik, L. Bell-Sakyi, E. De Vries, W.I. Morrison and F. Jongejan, Differential transcription of the major antigenic protein 1 multigene family of Ehrlichia ruminantium in Amblyomma variegatum ticks, Vet. Microbiol. 122 (2007), pp. 298-305.

Steyn et al., 2003 H.C. Steyn, H. Van Heerden, M.T.E.P. Allsopp and B.A. Allsopp, Variability of pCS20 gene sequence among different Ehrlichia ruminantium isolates, Ann. N.Y. Acad. Sci. 990 (2003), pp. 723-725.

Van Heerden et al., 2004a H. Van Heerden, N.E. Collins, K.A. Brayton, C. Rademeyer and B.A. Allsopp, Characterization of a major outer membrane protein multigene family in Ehrlichia ruminantium, Gene 330 (2004), pp. 159-168.

Van Heerden et al., 2004b H. Van Heerden, H.C. Steyn, M.T.P. Allsopp, E. Zweygarth, A.I. Josemans and B.A. Allsopp, Characterization of the pCS20 region of different Ehrlichia ruminantium isolates, Vet. Microbiol. 101 (2004), pp. 279-291.

Waghela et al., 1991 S.D. Waghela, F.R. Rurangirwa, S.M. Mahan, C.E. Yunker, T.B. Crawford, A.F. Barbet, M.J. Burridge and T.C. McGuire, A cloned DNA probe identifies Cowdria ruminantium in Amblyomma variegatum ticks, J. Clin. Microbiol. 29 (1991), pp. 2571-2577.

Wilson, 1997 I.G. Wilson, Inhibition and facilitation of nucleic acid amplification, Appl. Environ. Microbiol. 63 (1997), pp. 3741-3751.

Zweygarth et al., 2002 E. Zweygarth, A.I. Josemans, M.F. Van Strijp, H. Van Heerden and M.T.E.P. Allsopp, The Kümm isolate of Cowdria ruminantium: in vitro isolation, propagation, and characterization, Onderstepoort J. Vet. Res. 69 (2002), pp. 147-151.

Corresponding author. Tel.: +27 12529 9205; fax: +27 125299417. 